\title{
The impact of multi-criteria performance measurement on business performance improvement
}

\author{
Fentahun Moges Kasie, ${ }^{1}$ Alemu Moges Belay ${ }^{2}$ \\ ${ }^{1}$ Department of Mechanical and Industrial Engineering, Hawassa University (Ethiopia) \\ ${ }^{2}$ Norwegian University of Science and Technology, Design Engineering and Material (Norway) \\ fentabunmk@gmail.com,alemu.m.belay@ntnu.no
}

Received: May 2012

Accepted: March 2013

\section{Abstrad:}

Purpose The purpose of this paper is to investigate the relationship between multi-criteria performance measurement (MCPM) practice and business performance improvement using the raw data collected from 33 selected manufacturing companies. In addition, it proposes modified MCPM model as an effective approach to improve business performance of manufacturing companies.

Design/mathoddogy/approadr Research paper. Primary and secondary data were collected using questionnaire survey, interview and observation of records. The methodology is to evaluate business performances of sampled manufacturing companies and the extent of utilization of crucial financial (lagging) and non-financial (leading) performance measures. The positive correlation between financial business performance and practice of MCPM is clearly shown using Pearson's correlation coefficient analysis.

Findings: This research paper indicates that companies which measure their performance using important financial and non-financial measures achieve better business performance. Even though certain companies are currently using non-financial measures, the researchers have learned that these non-financial measures were not integrated with each other, financial measures and strategic objectives. 
Research limitations/implications: The limitation of this paper is that the number of surveyed companies is small to make generalization and they are found in a single country. Future research which incorporates a large number of companies from various developing nations is suggested to overcome the limitation of this research.

Practical implications: The paper shows that multi-dimensional performance measures with inclusion of key leading indicator are essential to predict the future business environment. But cost-accounting based financial measures are inadequate to do so. These are shown practically using Pearson's correlation coefficient analysis.

Originality/value The significance of multi-dimensional performance measures for business improvement in developing countries has been an issue among researchers. The originality of the paper is evident in the proposal of MCPM model, considering problems being faced by some manufacturing firms leading to low performance.

Keywards: performance measure, performance improvement, benchmark, business performance, manufacturing

\section{Introduction and problem background}

Recently, manufacturing philosophies and business environments are changing continuously. The crucial drivers are enhanced global competition, reduced product life cycle, technological advancement and customer requirement (Lockamy III, 1998). For companies to be competent in a dynamic market situation, one of the crucial requirements is devising appropriate performance measures (Bititci, 1994; Medori \& Sleeple, 2000; Kennerley \& Neely, 2003). Companies across the globe have been struggling to design performance measures specific to the nature of their businesses (Neely, 1999; Valiris \& Chytas, 2005). This is because traditional performance measures which are largely dependent upon finance have been criticized by many researchers (Johnson \& Kaplan, 1987; Bititci, 1994; White, 1996; Neely, Richards, Mills, Platts \& Bourne, 1997; Amaratunga, Baldry \& Sarshar, 2001; Tangen, 2004; Valiris \& Chytas, 2005), these financial measures are short-term, lagging indicators and are not proactive to indicate the present and future (Browne \& Devlin, 1998; Medori \& Steeple, 2000). Performance measures incorporating financial and non-financial indicators are much significant for process management (Franceschini, Galetto \& Maisano, 2007; Maksoud \& Kader, 2007). According to Neely (1999), organizations of top performers are those balancing financial and non-financial measures; linking strategies with measures of operations. 
Performance measurement is a critical element of decision-making and business performance improvement. It is imperative that companies develop and implement a multi-dimensional performance measurement system for proper decision making on their business performance, this is because the traditional cost-accounting measurement systems are with a number of shortcomings as mentioned earlier. During the past two decades, there was a revolution in the development of performance measurement and various frameworks were proposed and developed to replace traditional accounting based measures like balanced scorecard (BSC), performance prism, results determinants matrix, etc., but a few researches focused on the positive and/or negative relationship between performance measures and business performance (Bourne, Melnyk \& Faull, 2007). Most of such king of research has been carried out in advanced manufacturing firms in developed nations. This article is intended to fill the gap by tackling the shortcomings of traditional thinking performance measurement with reference to manufacturing companies in developing nations. This is because very limited research has been conducted in developing countries and those companies which are small and/or medium-sized and labor-intensive companies. Manufacturing firms which are labor intensive and found in developing nations have vacant space for similar research.

The problem statement in this paper focuses on multi-criteria performance measurement (MCPM), an important factor for performance improvement of manufacturing enterprises in developing countries. It analyses the relationship between MCPM (independent variable) and performance improvement (dependent variable). The objective of this paper is to study the relationship between business performance \& performance measurement (with inclusion of financial \& non-financial indicators) of selected companies and finally to propose MCPM model as a tool that will facilitate the improvement of their business performance. In order to address its problem statement and objective, this paper discusses state-of-the-art of performance measures; assess business performance and performance measurement activities, and the impact of MCPM (positive) and traditional cost-accounting performance measures (negative) on business results in the manufacturing companies surveyed.

In order to fulfill the above stated purpose and problem of statement, the following research questions have to be answered in different parts of this paper.

- What is the state-of-the-art of performance measurement in today's business environment?

- What is the relationship between utilization of financial \& non-financial performance measures and business performance in selected manufacturing companies?

- How do we propose a MCPM model that improves the business performance of manufacturing companies?

The contribution of this research paper is the proposal of a modified MCPM model for manufacturing companies in developing nations. It is expected to guide the companies to 
make important decisions for their future business performance improvement. Beneficiaries of the end results of this research paper are expected to be: (1) managers and owners of manufacturing companies that will assess their performance and (2) government bodies who will follow up the performance of state-owned manufacturing companies.

This paper is structured as follows; it starts with a brief an introduction on the background of the problem statement. Secondly, fundamental reviews of literature regarding basic concepts of performance measures, trends of performance measures, the relationship between a MCPM and performance improvement are discussed. Next, the research methodology is briefly outlined to indicate how the research was conducted. Then it continues with the data analysis and discussion which shows practical financial results, use of important financial and nonfinancial measures, and the positive relationship between the practice of non-financial measures and business performance. A MCPM model is also proposed in order to improve the existing measurement practices in most of the companies.

\section{Review of literature}

This part of the paper is intended to address the first research question in-depth and the second research question partly. It starts with a brief discussion of fundamental ideas of performance measures. The second part describes the development and evolution of MCPM model/frameworks by reviewing various literatures within the past three decades. The relationship between MCPM and performance measures is also discussed briefly at the end. In this paper MCPM refers to a performance measurement model/framework which incorporates both critical financial and non-financial measures in a balanced approach.

\subsection{Fundamental concepts of performance measures}

Much has been written on the subject of performance measurement by different researchers. To emphasize the development of appropriate performance measures is a crucial issue that helps to ensure competitiveness in global market and improve performance continuously. Lord Kelvin, a renowned British physicist, says "When you can measure what you are speaking about, and express it in numbers, you will know something about it...[otherwise] your knowledge is of a meager and unsatisfactory kind; it may be the beginning of knowledge, but you have scarcely in thought advanced to the stage of science" (Neely, 1998; Tangen, 2004). Neely, Gregory and Platts (1995) describes "performance measurement as the process of quantifying action, where measurement is the process of quantification and action correlates with performance". He further proposed that performance measures should be defined as efficiency and effectiveness of action (Neely et al., 1995; Neely, 1999; Gomes, Yasin \& Lisboa , 2004). "Measurement done right can transform your organization. It can not only show you where you are now, but can get you to wherever you want to go" (Spitzer, 2007). It is also quoted "performance measurement system is the heart of the performance management process and managerial decision for the company's performance improvement" (Bititci, Carrie 
\& Mc Devitt, 1997). Neely et al. (1997) says "Performance measures are the lifeblood of organizations, since without them no decisions can be made". The ideas behind these quotes indicate the significance of performance measures in order to improve performance. In addition, the importance of performance measures are reviewed in (Tangen, 2004; Artley, 2001; Holloway, 1999; Neely, 1998); these are formulate strategy, manage the strategy, check position and benchmark best practices, communicate employee and external stakeholders, give feedback and reward employee, improve decision making, and enhance improvement and learning.

The characteristics of effective and efficient performance measures are described in (Parmenter, 2010; Artley, 2001; Gomes et al., 2004; Neely et al., 1995; Neely et al., 1997; Tangen, 2004; Yuksel, 2004). These are summarized as follows: aligns daily activities to strategic objectives, have a balance between critical measures and have a limited number of performance measures, be easily accessible, have a clear purpose and a target for each performance measure and a timeframe for targets, guard against sub-optimal; Developed by users; consider improvement in performance, combine leading and lagging indicators, and motivate employees. Moreover, Neely et al. (1997) reviewed 22 recommendations of performance measures from various sources.

\subsection{Trends in performance measures}

Traditional performance measures were applied many years ago. There are arguments that they were first used as the double entry bookkeeping was applied in Venice around $14^{\text {th }}$ century (Zairi, 1996). At the beginning $20^{\text {th }}$ century, the environment of organizations had changed, and ownership and management were also separated, due to this, financial measures like return on investment were applied by owners in order to monitor the performance of their managers and employees (Kennerley \& Neely, 2003). In 1903, three DuPont cousins consolidated their small enterprises and completely reorganized the American explosives industry and installed an organizational structure that incorporated the "best practice" of the day (Neely, 1999). Cost and accounting management techniques were developed in the 1930s for independent auditing and linked to external financial operating systems (Bourne, Neely, Mills \& Platts, 2003).

By the 1980s, many researchers and business practitioners realized that, traditional cost-based performance measures were insufficient to manage organizations competing in modern markets where changes have been occurring in technology and production techniques (Lockamy III, 1998; Neely, 1998). Their usefulness has been questioned, especially related to manufacturing strategies (White, 1996). In order to resolve certain basic shortfalls, a new cost accounting method that is known as activity-based costing $(A B C)$, was developed by Johnson and Kaplan in the late 1980s (Tangen, 2004). But researchers argued that ABC would not solve the entire problem with financial measures, because other measures rather than costs were 
required to measure satisfactorily manufacturing performance relative to a competitive strategy (Neely et al., 1997).

In today's competitive markets, traditional finance-based measurements are most inappropriate predicting the future and take proactive actions. According to Browne and Devlin (1998) "These out-of-date techniques are at best irrelevant and at worst positively harmful". Many researchers have criticized their limitations (Kaplan \& Norton, 1996a; Akkermans \& Oorschot, 2002; Bititci, 1994; Gomes et al., 2004; Neely, 1999; Neely, Mills, Platts, Richards \& Bourne, 2000; White, 1996; Yuksel, 2004; Tangen, 2004; Parida, 2006); they stressed that traditional cost accounting measures that are too historical to forecast the future, highly distorted for future and long-term decision, lacking in response the effects of customers and other key stakeholders, do not encourage decentralization, inhibit continuous improvement and innovation; short-term and internally focused, and lack integration of strategies with performance measures.

Following the above criticisms, various performance measurement paradigms have been experienced over the last few decades. Among the most widely recognized ones are balanced scorecard, BSC (Kaplan \& Norton, 1996a) and the performance prism (Neely \& Adams, 2000). BSC proposes four interconnected perspectives of performance measurement in which measures of internal business process performance and learning and growth are derived from shareholders' and customers' views of performance. The performance prism proposed by Neely and Adams (2000) is also based on interconnected perspectives on measurement, illustrated by the facets of a prism. Other contributions to performance measurement system design include the dynamic performance measurement system proposed by Bititci, Turner and Begemann (2000), the SMART performance pyramid (Lynch \& Cross, 1991) and the performance measurement questionnaire proposed by Dixon, Nanni and Vollmann (1990), which audits existing measures based on their effect on improvement and the importance of improvement in different areas and factors. Souza, Carpinetti, Van Aken and Groesbeck (2005) proposed a conceptual design of performance measurement and management system using a structured engineering approach. Some of BSC limitations highlighted by Lee and Amaral (2002) were; BSC is simply a static management dashboard, highly weighted by financial information while more important non-financial data and qualitative information are not being captured or synthesized.

It is true that measures are quantifiable metric of the results expressed, for example in terms of dollars, days saved in a process, or improvement in customer satisfaction and are traditionally centered on the main performance areas that are financial, operational, or functional (Otley, 1999; Hongren, Foster \& Datar, 1999). Such metrics have been used for many years in business (Govindarajan \& Gupta, 1985; Scott \& Tiessen, 1999; Abernethy, Bouwens \& Van Lent, 2003; Davis \& Albright, 2004; Simons, 2005), and tend to be derived from operational accounting and information systems. Side by side, several researchers have 
applied performance measurement in the business of manufacturing and services. For instance, (Bryceson \& Slaughter, 2010) studied and discussed the holistic performance metric system that improve internal supply chain coordination. Chen \& Chen (2007) studied a combination of the data envelopment analysis (DEA) and BSC and another study showed effective quality management through third-generation balanced scorecard (Andersen, Lawrie \& Savic, 2004). Other examples are; effective performance measurement for e-business (Hinton \& Barnes, 2008), application of research \& development organizations using integrated DEA-AHP technique (Jyoti, Banwet \& Desmukh, 2008), healthcare capacity measurement (Bamford \& Chatziaslan, 2009), implementing a new performance management system within a project-based organization (Cheng, Dainty \& Moore, 2006), marketing and performance evaluations in non-profit services (Mano, 2010), measurement and analysis of customer satisfaction (Fernández-González \& Prado, 2007), and prioritization of key performance indicators with perspective of an integration of AHP process (Shahin \& Mahbod, 2007).

Historical analysis of performance measurement and management in operations management (Radnor \& Barnes, 2007) reveals most of PMM within OM derived from work study and productivity measurement within manufacturing during the industrial revolution. Measuring performance via production management (Chen \& Liaw, 2006) and determining the business performance seems to be not completely correlated with the achievements of production management, since moderate production planning can provide optimal business performance. (Gosselin, 2005) studied an empirical study of performance measurements in manufacturing firms and gave an insight that performance measurement should be aligned with strategy and organizational structure that are non-financial measurements. The impact of performance measurement in strategic planning was studied by (Tapinos, Dyson \& Meadows, 2005) in support of Gosselin's study. Another insight into performance measurement is multi-factor productivity measurement model for service organization (Sahay, 2004) and it shows how different factors of static, dynamic and development parameters can be taken into account to calculate the total productivity of an organization. In addition, well-known performance measurement frameworks/models are presented in Table 1.

All the aforementioned reflect that performance measurement is a hot issue on decisionmaking in both manufacturing and service entities. Various performance measurement models and frameworks were proposed during the past two decades, no one is without criticism. These critics are described at large in a range of literature sources (Zairi, 1996; Neely, 1998; Tangen, 2004; Kidusan, 2004; Flak \& Dertz, 2004; Gilman \& Metawie, 2005; Parida, 2006). This indicates that performance measures are as dynamic as the rapidly changing of business environment. 


\begin{tabular}{|c|c|c|}
\hline Model/framework & Measures/Indicators/Criteria & Reference \\
\hline Sink and Tuttle (1989) & $\begin{array}{l}\text { Efficiency, Effectiveness, Quality, Productivity, Quality of } \\
\text { work life and innovation, Profitability/budget ability, } \\
\text { Excellence, survival and growth, }\end{array}$ & Sink and Tuttle (1989) \\
\hline Du Pont Pyramid & Financial ratios, Return on investment (ROI) & $\begin{array}{l}\text { Chandler (1977); Skousen et } \\
\text { al. (2001) }\end{array}$ \\
\hline PM matrix & Cost factors, Non-cost factors, External factors, Internal factors & Keegan et al. (1989) \\
\hline $\begin{array}{l}\text { Results and } \\
\text { determinants matrix }\end{array}$ & $\begin{array}{l}\text { Financial performance, Competitiveness, Quality, } \\
\text { Flexibility, Resource utilization, Innovation }\end{array}$ & Fitzgerald et al. (1991) \\
\hline PM questionnaire & $\begin{array}{l}\text { Strategies, actions and measures are assessed, Extent to } \\
\text { which they are supportive? Data analysis as per management } \\
\text { position or function, Range of response and level of } \\
\text { disagreement }\end{array}$ & Dixon et al. (1990) \\
\hline Brown's framework & $\begin{array}{l}\text { Input measures, Process measures, Output measures, } \\
\text { Outcome measures }\end{array}$ & Brown (1996) \\
\hline $\begin{array}{l}\text { SMART pyramid } \\
\text { (Performance } \\
\text { pyramid) }\end{array}$ & $\begin{array}{l}\text { Quality, Delivery, Process time, Cost, Customer satisfaction, } \\
\text { Flexibility, Productivity, Marketing measures, Financial } \\
\text { measures }\end{array}$ & $\begin{array}{l}\text { Developed by Wang } \\
\text { Laboratories. } \\
\text { Lynch and Cross (1991) }\end{array}$ \\
\hline $\begin{array}{l}\text { Balanced Scorecard } \\
\text { (BSC) }\end{array}$ & Financial, Customer, Internal processes, Learning \& growth & Kaplan \& Norton (1992) \\
\hline Consistent PM system & $\begin{array}{l}\text { Derived from strategy, continuous improvement, fast and } \\
\text { accurate feedback, explicit purpose, relevance }\end{array}$ & Flapper et al. (1996) \\
\hline $\begin{array}{l}\text { Framework for small } \\
\text { business PM }\end{array}$ & $\begin{array}{l}\text { Flexibility, Timeliness, Quality, Finance, Customer } \\
\text { satisfaction, Human factors }\end{array}$ & Laitinen (1996) \\
\hline $\begin{array}{l}\text { Cambridge PM } \\
\text { process }\end{array}$ & $\begin{array}{l}\text { Quality, Flexibility, Timeliness, Finance, Customer } \\
\text { satisfaction, Human factors }\end{array}$ & Neely et al. (1997) \\
\hline $\begin{array}{l}\text { Integrated dynamic } \\
\text { PM System }\end{array}$ & $\begin{array}{l}\text { Timeliness, Finance, Customer satisfaction, Human factors, } \\
\text { Quality, Flexibility }\end{array}$ & Ghalayini et al. (1997) \\
\hline $\begin{array}{l}\text { Integrated PM } \\
\text { framework }\end{array}$ & Quality, Flexibility, Timeliness, Finance, Customer satisfaction & Medori and Steeple (2000) \\
\hline Integrated PM system & $\begin{array}{l}\text { Finance, Customer satisfaction, Human factors, Quality, } \\
\text { Flexibility, Timeliness }\end{array}$ & Bititci (1994) \\
\hline Dynamic PM Systems & $\begin{array}{l}\text { External and internal monitoring system, Review system, } \\
\text { Internal deployment system, IT platform needs }\end{array}$ & Bititci et al. (2000) \\
\hline $\begin{array}{l}\text { Integrated } \\
\text { Measurement model }\end{array}$ & $\begin{array}{l}\text { Customer satisfaction, Human factors, Quality, Flexibility, } \\
\text { Timeliness, Finance }\end{array}$ & Oliver \& Palmer (1998) \\
\hline $\begin{array}{l}\text { Comparative Business } \\
\text { Scorecard }\end{array}$ & $\begin{array}{l}\text { Stakeholder value, Delight the stakeholder, Organizational } \\
\text { learning, Process excellence }\end{array}$ & Kanji (1998) \\
\hline Skandia Navigator & $\begin{array}{l}\text { Financial focus, Customer focus, Human focus, Process } \\
\text { focus, Renewal and development focus }\end{array}$ & $\begin{array}{l}\text { Edvinsson and Malone } \\
\text { (1997); Sveiby (1997) }\end{array}$ \\
\hline $\begin{array}{l}\text { Balanced IT Scorecard } \\
\text { (BITS) }\end{array}$ & $\begin{array}{l}\text { Financial perspective, Customer satisfaction, Internal } \\
\text { processes, Infrastructure \& innovation, People perspective }\end{array}$ & $\begin{array}{l}\text { ESI (1998) as mentioned in } \\
\text { Abran and Buglione (2003) }\end{array}$ \\
\hline $\begin{array}{l}\text { BSC of Advanced } \\
\text { Information. Services } \\
\text { Inc (AISBSC) }\end{array}$ & $\begin{array}{l}\text { Financial perspective, Customer perspective } \\
\text { Processes, People, Infrastructure \& innovation }\end{array}$ & Abran and Buglione (2003) \\
\hline $\begin{array}{l}\text { Intangible Asset- } \\
\text { monitor (IAM) }\end{array}$ & $\begin{array}{l}\text { Internal Structure: *Growth, *Renewal, *Efficiency, *Stability, } \\
\text { Risk (Concept models, Computers, Administrative systems); } \\
\text { External Structure: *Customer, *Supplier, *Brand names, } \\
\text { *Trademark \& image; Individual Competence: * Skills, } \\
\text { *Education*Experience, *Values, "Social skill }\end{array}$ & Sveiby (1997) \\
\hline Performance Prism & $\begin{array}{l}\text { Stakeholders satisfaction, strategies, processes, capabilities, } \\
\text { stakeholders contribution }\end{array}$ & Neely and Adam (2000) \\
\hline QUEST & Quality, Economic, Social and Technical factors & Abran \& Buglione (2003) \\
\hline $\begin{array}{l}\text { European Foundation } \\
\text { for Quality } \\
\text { Management (EFQM) }\end{array}$ & $\begin{array}{l}\text { Leadership, Enablers: people management, policy and } \\
\text { strategy, resources; Processes, Results: people and customer } \\
\text { satisfaction, impact on society; and Business results }\end{array}$ & $\begin{array}{l}\text { http://www.efqm.org/ as } \\
\text { mentioned in Wongrassamee } \\
\text { et al.(2003) }\end{array}$ \\
\hline
\end{tabular}

Table1. Compiled summary of performance measurement models/frameworks (Parida, 2006) 


\subsection{Relation between MCPM and Business Performance}

The limitations in traditional measures have caused a revolution in performance measurement during the three decades to achieve competitiveness and improve their business performance particularly in manufacturing. This revolution has led researchers and business practitioners to focus on the design and implementation of new performance measures. For example, according to Neely (1999), 3,615 articles on performance measurement were published between 1994 and 1996, and in the USA only new books on the subject appeared at a rate of one every two weeks. In 1994 the UK government declared: "to achieve sustainable business in the demanding world marketplace, a company must...use relevant performance measure" (Neely, 1998). As per a 1996 corporate performance measurement study of 312 American organizations, those using financial measures were only $27 \%$; the remaining $73 \%$ performance indicators such as product/service quality, customer satisfaction, productivity, workforce, and market indicators (Neely, 1999).

Bourne et al. (2007) describes a multi-dimensional performance measurement systems developed and proposed in the 1980s. But, less attention is provided on the impact of the new approaches on business performance; this has elicited the need to devote studies to on their impacts on improvement of business performance. In the 1990s, the British Rail's Network South-East, used appropriate MCPM to grow off-peak income by $28 \%$, and reduce controllable costs by $30 \%$, leading to service delivery and customer satisfaction improvement from the worst level to the best ever (Neely, 1999). Another successful manufacturing company that applied MCPM is Tektronix in US. Its performance measures were designed to adopt a strategy of continuous improvement and the performance improvements were remarkable; cycle time reduced from an average of 25 weeks to 7 days, inventory levels reduced by $80 \%$, while sales increased, work-in-progress decreased from 1,500 to 125 , floor space occupied by divisions dropped by more than $50 \%$, five separate product lines were grouped into one line, vendors decreased from 1,500 to fewer than 200 , greater than $70 \%$ of sales delivered within due date; market shares increased; and profitability was excellent (Neely et al., 1997).

Research carried out at the University of Michigan and the Stockholm School of Economics on the Swedish Customer Satisfaction Barometer, realized the important positive correlation between customer satisfaction and financial performance; this research has revealed an annual one-point increase in customer satisfaction at a net present value of $\$ 7.48$ million over five years for a typical firm in Sweden (Neely, 1999). A research conducted in 1998 by Gallup in the US has also reported tremendous outputs of companies achieving higher levels of employee satisfaction than their rivals whom they outperform by $22 \%$ in terms of productivity, $38 \%$ in terms of customer satisfaction, $27 \%$ in terms of profitability and $22 \%$ in terms of employee retention (Neely, 1998). Besides, data from the USA research company, the Gartner group, suggest that $40 \%$ of the largest businesses in the USA had adopted the balanced scorecard by the end of 2000 (Kennerley \& Neely, 2003). (Kidusan, 2004) indicated a positive correlation between non- 
financial performance measurement (customer, internal business process, and employee measures) and financial business results, specifically, sales growth and return on total asset.

\subsection{Summary of literature}

In the literature, part of fundamental practices and ideas regarding performance measures; have been discussed in response to the first research question and partly to the second question. The state-of-the-art of MCPM and its revolution have been described from highly rated literature. During the past three decades, research on the subject of performance measurement has become hot issues for companies in the quest to attain competitive status in the global markets, since traditional cost accounting techniques have faced many pitfalls. Various MCPM models/frameworks were proposed to alleviate the shortcoming of traditional measures.

As mentioned earlier, the impact of these frameworks on performance has not been given more attention i.e. the relationship between MCPM and business performance should be studied explicitly. However, very few studies carried out to reveal the relationship between non-financial performance measures or MCPM and improvement in business performance; these studies are limited in developed countries. So, this research intended to consider firms in developing nations to integrate non-financial performance measures to the strategic plan and enhance their productivity. Manufacturing companies in developing nations are largely characterized by their poor business performance. This paper focuses on development of MCPM framework that improves the performance of such manufacturing companies.

\section{Research methodology}

This part of the paper briefly presents the research methods that have been employed. We used mixed research approaches and research strategies.

\subsection{Quantitative and qualitative research approaches}

This research was undertaken by applying a combination of both qualitative and quantitative research approaches. Quantitative techniques were employed to analyze financial business performance and MCPM application in selected manufacturing companies. Qualitative approaches were also employed to develop MCPM model. They were used as open-ended observations \& interviews for obtaining detailed answers to "how" and "why" questions from concerned personnel in companies and supervising agencies. The strategy map for a proposed MCPM model has been outlined by qualitative research approaches.

\section{Research strategies}

As per the research objectives for this paper, research strategies such as literature review, survey of the questionnaire, face-to-face interview, and archival records \& document observation were applied. 


\section{Literature review}

Various sources of literature were surveyed from international journals, book reviews, magazines, websites, and conference proceedings in order to answer some of the research questions. They were essential for describing the fundamental concepts of performance measurement, reviewing evolution and revolution of performance measurement models/frameworks and criticizing finance based traditional measures. This strategy has offered satisfactory answers to the research question "What is the state-of-art-of performance measurement in today's business environment?" The strategy also established the relationship between MCPM and business performance improvement of certain companies that had been successful in designing their MCPM frameworks.

\subsection{Data collection}

33 state owned manufacturing companies were surveyed in the research. The surveyed companies with their manufacturing sectors were categorized as shown in Table 2. The respondents' profiles are shown in Table 3. Ranges of organizations' full-time workers are shown in Table 3. The respondents' educational qualification level is as follows: $3 \%$ are technical \& vocational school graduates, $14 \%$ are diploma graduates, and the remaining $83 \%$ are university graduates. Companies were selected randomly considering their convenience to the researchers' data collection purpose. This survey was conducted from March10 - April 30, 2007. All sampled companies are state-owned; this is so for two reasons, namely, most of the complex companies are state-owned and the private companies were not willing to provide information.

\begin{tabular}{|c|l|c|c|}
\hline SN & \multicolumn{1}{|c|}{ Manufacturing Sector } & Frequency & Percent \\
\hline 1 & Textile and garment & 6 & 18.2 \\
\hline 2 & Leather and leather products & 4 & 12.1 \\
\hline 3 & Food, sugar \& edible oil products & 11 & 33.3 \\
\hline 4 & Basic metal and metal products & 4 & 12.1 \\
\hline 5 & Beverage industries & 8 & 24.2 \\
\hline & Total & 33 & 100 \\
\hline
\end{tabular}

Table 2. Sampled companies in five manufacturing sectors

\begin{tabular}{|c|l|c|c|}
\hline SN Job Position & Frequency & Percent \\
\hline 1 & General manager & 2 & 5 \\
\hline 2 & Production and technical manager & 7 & 17 \\
\hline 3 & Administrative manager & 2 & 5 \\
\hline 4 & Finance manager & 3 & 7 \\
\hline 5 & Commercial manager & 3 & 7 \\
\hline 6 & Management service head & 2 & 5 \\
\hline 7 & Plan \& information head & 14 & 33 \\
\hline 8 & Statistics export & 3 & 7 \\
\hline 9 & Public Enterprises Supervising Expert & 4 & 10 \\
\hline 10 & Ministry of Trade \& Industry Expert & 2 & 5 \\
\hline & Total & 42 & 100 \\
\hline
\end{tabular}

Table 3. Respondents' job title 


\begin{tabular}{|c|l|c|c|}
\hline SN & \multicolumn{1}{|c|}{ No of employees } & Frequency & Percent \\
\hline 1 & 150 and below & 4 & 12.1 \\
\hline 2 & $151-500$ & 11 & 33.3 \\
\hline 3 & $501-1000$ & 12 & 36.4 \\
\hline 4 & $1001-2000$ & 4 & 12.1 \\
\hline 5 & Above 2000 & 2 & 6.1 \\
\hline & Total & 33 & 100 \\
\hline
\end{tabular}

Table 4. Companies with different employee number categories

Three major data collection methods were applied such as questionnaire survey, interview and observation of documents.

\section{Questionnaire survey}

The survey instrument was designed based on knowledge obtained from various literature sources in the field of performance measurement. Its content was evaluated by five independent industry professionals and two academic professionals who are experts in the field performance measurement. Based on their comments, minor modifications were made in the draft instrument. Then the questionnaire was dispatched to relevant personnel to answer the questions. The purpose of the questionnaire is to assess the current business performance, and utilization of financial \& non-financial performance measures in selected manufacturing companies. The detail of the instrument is attached in the annexure.

\section{Interviews}

Face-to-face interview was carried out by special personnel. The aim of this interview was to get detailed information regarding challenges faced by manufacturing companies and also to determine what type of MCPM framework should be proposed for these companies. Interviewees with the under-listed titles were actively consulted during MCPM proposal (including strategy map and scorecard).

\begin{tabular}{|c|l|c|c|}
\hline SN & \multicolumn{1}{|c|}{ Job Title } & Frequency & Percent \\
\hline 1 & General manager & 1 & 8.3 \\
\hline 2 & Production \& technical manager & 3 & 25.0 \\
\hline 3 & Planning head & 4 & 33.3 \\
\hline 4 & Quality head & 2 & 16.7 \\
\hline 5 & Manufacturing sector head & 2 & 16.7 \\
\hline & Total & 12 & 100 \\
\hline
\end{tabular}

Table 5. Interviewed personnel

\section{Observation of documentations}

Supplementary secondary data were obtained from governmental organizations such as privatization and public enterprises supervising agencies, Ministry of Trade \& Industry, Central Statistics Authorities and from international sources like UNIDO and IMF reports. 


\section{Result presentation}

Data obtained using the above collection methods have been presented with the supporting of tables and diagrams. Microsoft spreadsheet was also applied to analyze the collected data. The indications of this analysis have been used to propose a MCPM model for manufacturing companies and to draw important conclusions. Secondary data were quantitatively analyzed to benchmark the financial performance of the selected companies with international industry norms. Financial performances such as profit margin, return on total asset (ROA), and sales growth were determined from an average of the previous four fiscal years. Employee productivity performances were also determined from their financial performance and number employees of the same fiscal year. Primary data have been analyzed in order to determine the extent of utilization of financial \& critical non-financial performance measure/indicators and their linkage with performance and strategic goals. The relationship between the use of nonfinancial measures and business performance improvement has been determined using Pearson's correlation coefficient analysis. The summarized statistical analysis is shown in Table 9. With reference to all the results of the data analysis, a MCPM model has been proposed as one of the ingredients to improve the performance of sampled manufacturing companies. This has been done using information as important input from a needs assessment survey, in-depth interviews with companies' representatives \& supervising agents, and standard literature surveys.

\subsection{Result discussion}

Here the findings of data collection are analyzed and discussed thoroughly. This part of the paper practically responds to research questions \#2 and \#3. The discussion focuses on companies' business performance, performance measurement using key financial and nonfinancial indicators, the relationship between performance measures and business performance, and proposal of MCPM model.

\section{Business performance}

Firstly, business performance of selected manufacturing companies is studied using performance indicators such as profit margin, return on total asset (ROA), sales growth, revenue/labor, and total asset/labor. The first three measures are financial and the last two are labor productivity measures. These performance results are compared with international industry benchmarks to make performance gap analysis as shown in the table below. We used few data from Industrial Development Report (2004) for benchmarking purpose.

The gap between actual performance and world average is computed using the formula:

$$
\text { Gap }=\text { AP - WA }
$$




\begin{tabular}{|c|c|c|c|c|c|c|c|c|c|}
\hline \multirow[t]{2}{*}{ SN } & \multirow{2}{*}{$\begin{array}{c}\text { Sales } \\
\text { Growth } \\
{[\%]}\end{array}$} & \multicolumn{2}{|c|}{$\begin{array}{l}\text { ROA [\%] } \\
\text { WA }=\mathbf{8 . 3 0}\end{array}$} & \multicolumn{2}{|c|}{$\begin{array}{l}\text { Profit margin }[\%] \\
\qquad W A=13.21\end{array}$} & \multicolumn{2}{|c|}{$\begin{array}{c}\text { Revenues/labor }[000 \$] \\
W A=236.90\end{array}$} & \multicolumn{2}{|c|}{$\begin{array}{c}\text { ROA/labor }[000 \$] \\
W A=752.17\end{array}$} \\
\hline & & AP & Gap & AP & Gap & AP & Gap & AP & Gap \\
\hline 1 & 45.95 & -32.61 & -40.91 & -58.52 & -71.73 & 4.37 & -232.53 & 8.53 & -742.64 \\
\hline 2 & -10.31 & -13.68 & -21.98 & -36.88 & -50.09 & 3.41 & -233.49 & 11.90 & -739.27 \\
\hline 3 & -8.96 & -23.28 & -31.58 & -43.82 & -57.03 & 2.20 & -234.70 & 7.47 & -743.70 \\
\hline 4 & 21.81 & -3.23 & -11.53 & -6.64 & -19.85 & 12.52 & -224.38 & 13.14 & -738.03 \\
\hline 5 & 6.93 & 21.22 & 12.92 & 31.05 & 17.84 & 80.88 & -156.02 & 61.07 & -690.10 \\
\hline 6 & 19.05 & 16.02 & 7.72 & 12.30 & -0.91 & 83.18 & -153.72 & 59.08 & -692.09 \\
\hline 7 & -8.61 & -0.02 & -8.32 & -0.04 & -13.25 & 23.53 & -213.37 & 51.39 & -699.78 \\
\hline 8 & 36.83 & 0.92 & -7.38 & 1.41 & -11.80 & 17.53 & -219.37 & 65.14 & -686.03 \\
\hline 9 & 11.10 & 41.55 & 33.25 & 24.79 & 11.58 & 31.88 & -205.02 & 19.18 & -731.99 \\
\hline 10 & 7.94 & 32.33 & 24.03 & 34.68 & 21.47 & 35.63 & -201.27 & 40.37 & -710.80 \\
\hline 11 & -3.81 & 4.54 & -3.76 & 5.38 & -7.83 & 15.61 & -221.29 & 23.52 & -727.65 \\
\hline 12 & 2.82 & -8.26 & -16.56 & -13.07 & -26.28 & 17.15 & -219.75 & 30.13 & -721.04 \\
\hline 13 & 12.95 & 9.64 & 1.34 & 7.42 & -5.79 & 27.37 & -209.53 & 19.27 & -731.90 \\
\hline 14 & -0.04 & -8.32 & -16.62 & -10.75 & -23.96 & 9.38 & -227.52 & 13.96 & -737.21 \\
\hline 15 & 4.27 & -0.88 & -9.18 & -0.08 & -13.29 & 59.54 & -177.36 & 64.23 & -686.94 \\
\hline 16 & 2.30 & -5.50 & -13.80 & -11.65 & -24.86 & 10.89 & -226.01 & 27.42 & -723.75 \\
\hline 17 & 4.96 & -8.14 & -16.44 & -9.45 & -22.66 & 7.47 & -229.43 & 11.53 & -739.64 \\
\hline 18 & 6.36 & -44.51 & -52.81 & -17.71 & -30.92 & 5.89 & -231.01 & 15.86 & -735.31 \\
\hline 19 & 4.93 & 10.01 & 1.71 & 18.56 & 5.35 & 30.80 & -206.10 & 47.12 & -704.05 \\
\hline 20 & -20.28 & -3.50 & -11.80 & -24.96 & -38.17 & 18.04 & -218.86 & 92.65 & -658.52 \\
\hline 21 & 5.58 & 4.92 & -3.38 & 6.63 & -6.58 & 79.09 & -157.81 & 83.66 & -667.51 \\
\hline 22 & -21.65 & -0.78 & -9.08 & -12.55 & -25.76 & 9.12 & -227.78 & 45.10 & -706.07 \\
\hline 23 & 10.20 & 10.27 & 1.97 & 7.01 & -6.20 & 18.82 & -218.08 & 12.27 & -738.90 \\
\hline 24 & -1.50 & 32.50 & 24.20 & 12.14 & -1.07 & 25.48 & -211.42 & 37.26 & -713.91 \\
\hline 25 & 51.85 & 3.16 & -5.14 & 8.49 & -4.72 & 14.92 & -221.98 & 23.22 & -727.95 \\
\hline 26 & 20.67 & -2.78 & -11.08 & -8.35 & -21.56 & 21.24 & -215.66 & 25.43 & -725.74 \\
\hline 27 & 2.40 & 12.48 & 4.18 & 15.07 & 1.86 & 131.53 & -105.37 & 120.22 & -630.95 \\
\hline 28 & 0.77 & 8.53 & 0.23 & 22.70 & 9.49 & 36.66 & -200.24 & 64.87 & -686.30 \\
\hline 29 & 43.84 & 7.73 & -0.57 & 18.39 & 5.18 & 24.06 & -212.84 & 56.63 & -694.54 \\
\hline 30 & 2.70 & 3.61 & -4.69 & 16.61 & 3.40 & 18.61 & -218.29 & 61.52 & -689.65 \\
\hline 31 & 23.61 & 12.52 & 4.22 & 15.28 & 2.07 & 30.97 & -205.93 & 83.26 & -667.91 \\
\hline 32 & 4.04 & 6.17 & -2.13 & 16.15 & 2.94 & 114.00 & -122.90 & 118.60 & -632.57 \\
\hline 33 & 19.10 & 13.40 & 5.10 & 21.46 & 8.25 & 88.43 & -148.47 & 68.90 & -682.27 \\
\hline AV. & 9.02 & 2.91 & -5.39 & 1.24 & -11.97 & 33.64 & -203.26 & 44.97 & -706.20 \\
\hline St.dev & 17.16 & 17.07 & 17.07 & 21.18 & 21.18 & 33.17 & 33.17 & 31.16 & 31.16 \\
\hline Max. & 51.85 & 41.55 & 33.25 & 34.68 & 21.47 & 131.53 & -105.37 & 120.22 & -630.95 \\
\hline Min & -21.65 & -44.51 & -52.81 & -58.52 & -71.73 & 2.20 & -234.70 & 7.47 & -743.70 \\
\hline
\end{tabular}

$\mathrm{AP}=$ actual performance; $\mathrm{WA}=$ world average; $\mathrm{SN}=$ serial \# of surveyed companies.

Table 6. Summary of companies' business performance. Researchers' computation from survey results, and sources for global norms: Philip M. Parker, Professor, INSEAD, and copyright 2003 cited at http://www.icongrouponline.com/chapterview sample. $a s p ?$ sid $=\& i s b n=059751299 \times \&$ chap $=5$ 


\begin{tabular}{|c|l|c|c|}
\hline \multirow{2}{*}{ SN } & \multicolumn{1}{|c|}{ Performance indicator } & \multicolumn{2}{c|}{ Enterprises below international norm } \\
\cline { 3 - 4 } & [Number] & $6 \%$ ] \\
\hline 1 & Profit margin & 18 & 54.55 \\
\hline 2 & ROA & 33 & 100 \\
\hline 3 & Revenue per labor & 33 & 100 \\
\hline 4 & Total asset per lobar & 22 & 67 \\
\hline
\end{tabular}

Table 7. Number of enterprises below world average

As shown in Table 6, five business performance indicators are selected to be benchmarked with international norm averages. In the case of profit margin around $67 \%$ of sampled companies are well-behind the international norm and about 55\% below the norm regarding return on total asset. All companies are at levels much below the international norm with respect to labor-productivity performance indicators such as revenue per employee and total asset per employee. From these performance indicators, it is clear that sample companies are not working at a satisfactory level and they need change to improve their business performance.

Figure 1 indicates gap between a financial ratio of surveyed enterprises and world benchmarks in terms of profit margin. Figure 2 also reveals labor productivity variations between surveyed organizations and international norms graphically in terms of revenues per labor.

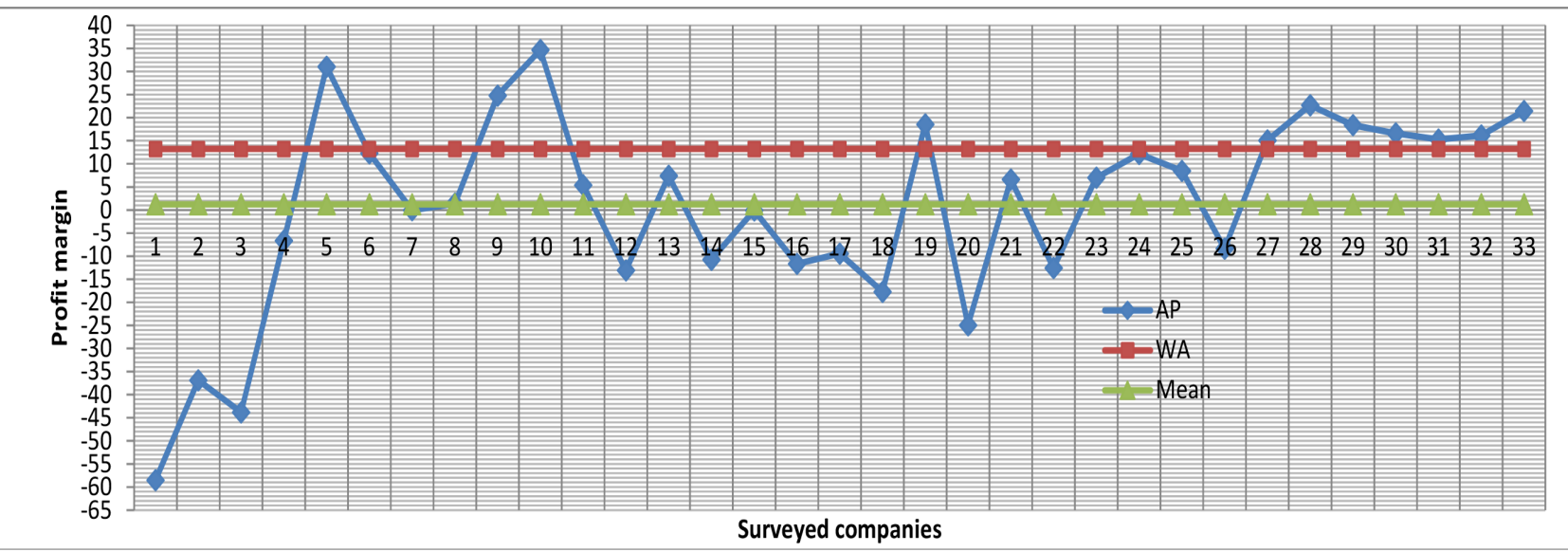

Figure1. Line chart to show gap between actual performance and world average in profit margin

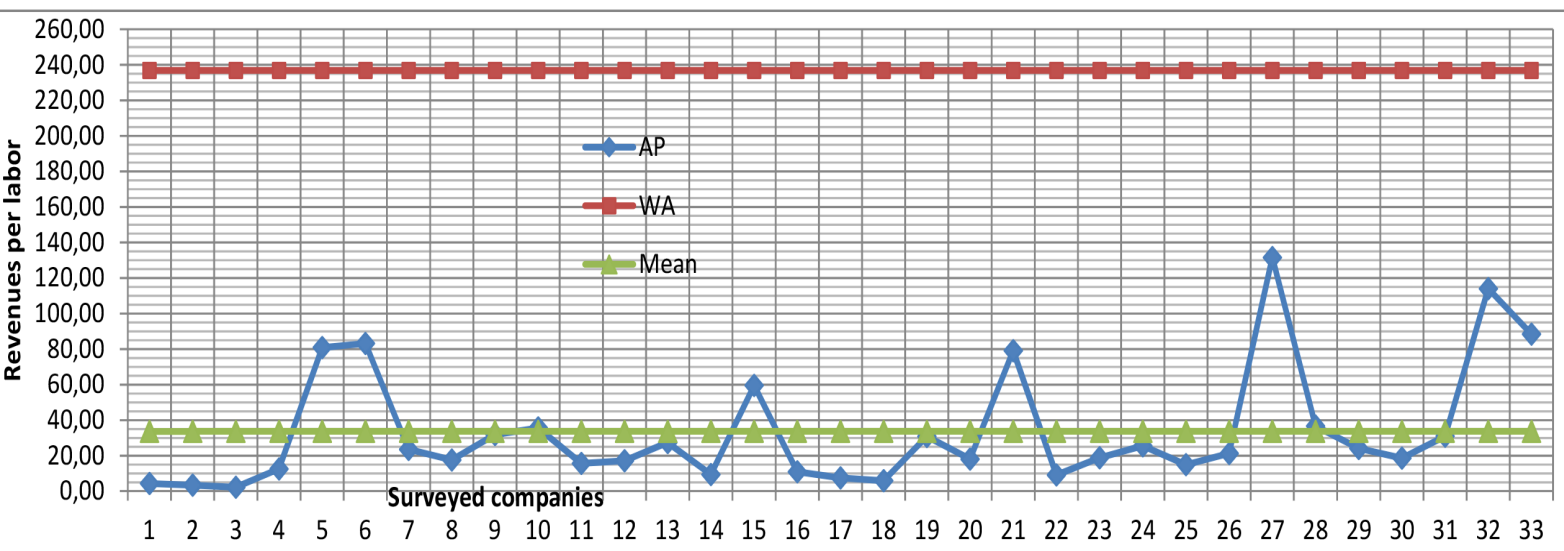

Figure 2. Line chart to show gap between actual performance and world average in revenues per labor 


\section{Use of financial and non-financial performance measures}

Secondly, primary data have been analyzed to investigate how many companies are using financial and non-financial measures during their decision making in selected manufacturing organizations. Respondents were requested to rate their firms to what extent they are apply both lagging (financial) and leading (non-financial) performance indicators with five Likert scales. The compiled results are shown in Table 8 with respect to seven important measurement perspectives. According to the findings, selected manufacturing companies are using financial measures at large extent such as capacity, capital budget, investment, production volume, efficiency, effectiveness, ROA, profit margin, ROCE, etc. but at very low extent leading indicators.

\begin{tabular}{|c|c|c|c|c|c|c|c|}
\hline \multirow[b]{2}{*}{ SN } & \multicolumn{7}{|c|}{ Performance measurement practice scores } \\
\hline & Finance & $\begin{array}{l}\text { Customer } \\
\text { \& Market }\end{array}$ & $\begin{array}{l}\text { Process/ } \\
\text { Operation }\end{array}$ & $\begin{array}{l}\text { Employee } \\
\text { Satisfaction }\end{array}$ & $\begin{array}{l}\text { Training \& } \\
\text { Development }\end{array}$ & $\begin{array}{c}\text { Social \& } \\
\text { Environmental }\end{array}$ & $\begin{array}{l}\text { Supplier } \\
\text { partnership }\end{array}$ \\
\hline 1 & 4.50 & 1.25 & 2.00 & 1.25 & 1.00 & 1.00 & 1.00 \\
\hline 2 & 5.00 & 1.00 & 1.30 & 1.25 & 1.00 & 1.00 & 2.00 \\
\hline 3 & 4.00 & 1.25 & 1.30 & 1.00 & 1.00 & 1.33 & 1.00 \\
\hline 4 & 4.25 & 1.75 & 2.00 & 2.25 & 1.75 & 1.67 & 1.50 \\
\hline 5 & 4.50 & 3.00 & 3.80 & 3.00 & 3.00 & 4.00 & 2.50 \\
\hline 6 & 4.25 & 5.00 & 4.00 & 3.50 & 3.75 & 4.00 & 4.00 \\
\hline 7 & 4.75 & 2.50 & 3.20 & 3.25 & 2.50 & 2.33 & 2.00 \\
\hline 8 & 4.50 & 3.25 & 3.60 & 2.75 & 3.00 & 2.33 & 2.33 \\
\hline 9 & 4.50 & 2.75 & 3.60 & 2.50 & 2.75 & 2.67 & 3.00 \\
\hline 10 & 4.25 & 2.50 & 4.25 & 3.50 & 3.00 & 3.00 & 4.00 \\
\hline 11 & 4.25 & 2.25 & 3.20 & 1.75 & 2.25 & 1.00 & 2.00 \\
\hline 12 & 4.00 & 1.50 & 2.60 & 1.25 & 2.75 & 1.67 & 2.33 \\
\hline 13 & 5.00 & 3.00 & 3.80 & 2.50 & 2.25 & 1.00 & 3.00 \\
\hline 14 & 3.25 & 2.00 & 2.00 & 1.00 & 1.00 & 1.00 & 1.00 \\
\hline 15 & 4.50 & 2.50 & 2.80 & 2.50 & 2.25 & 1.33 & 2.00 \\
\hline 16 & 4.25 & 2.00 & 3.25 & 2.00 & 2.00 & 3.33 & 2.33 \\
\hline 17 & 4.00 & 2.00 & 2.50 & 1.00 & 1.00 & 1.33 & 1.67 \\
\hline 18 & 4.25 & 1.75 & 2.75 & 2.00 & 2.00 & 1.67 & 2.00 \\
\hline 19 & 4.75 & 3.00 & 3.80 & 2.50 & 2.75 & 2.33 & 2.33 \\
\hline 20 & 4.50 & 1.75 & 2.75 & 2.50 & 3.00 & 1.67 & 2.00 \\
\hline 21 & 5.00 & 2.75 & 3.60 & 3.25 & 3.25 & 3.33 & 3.67 \\
\hline 22 & 4.00 & 2.00 & 2.25 & 1.50 & 1.50 & 1.00 & 1.67 \\
\hline 23 & 4.75 & 2.75 & 3.40 & 3.00 & 2.75 & 2.33 & 3.00 \\
\hline 24 & 4.00 & 3.25 & 4.25 & 3.25 & 2.50 & 3.00 & 3.00 \\
\hline 25 & 4.75 & 2.50 & 2.60 & 1.75 & 2.00 & 2.33 & 2.00 \\
\hline 26 & 4.50 & 2.50 & 3.00 & 2.50 & 2.00 & 2.67 & 2.50 \\
\hline 27 & 4.75 & 2.75 & 3.00 & 2.75 & 2.25 & 3.00 & 2.33 \\
\hline 28 & 5.00 & 2.50 & 3.25 & 2.50 & 2.75 & 2.33 & 2.67 \\
\hline 29 & 4.50 & 2.00 & 3.20 & 2.50 & 2.50 & 2.25 & 2.00 \\
\hline 30 & 3.75 & 2.25 & 3.00 & 1.50 & 2.25 & 2.25 & 1.25 \\
\hline 31 & 4.75 & 2.75 & 3.40 & 2.00 & 2.50 & 2.50 & 2.25 \\
\hline 32 & 4.25 & 3.50 & 4.75 & 4.50 & 4.25 & 3.75 & 2.50 \\
\hline 33 & 5.00 & 2.75 & 3.50 & 3.75 & 3.00 & 2.75 & 2.25 \\
\hline Av. & 4.43 & 2.43 & 3.08 & 2.36 & 2.35 & 2.22 & 2.28 \\
\hline Std & 0.41 & 0.77 & 0.81 & 0.88 & 0.79 & 0.91 & 0.75 \\
\hline Max & 5.00 & 5.00 & 4.75 & 4.50 & 4.25 & 4.00 & 4.00 \\
\hline Min & 3.25 & 1.00 & 1.30 & 1.00 & 1.00 & 1.00 & 1.00 \\
\hline
\end{tabular}

Table 8. Financial and non-financial performance measures utilization 
Around $50 \%$ of selected companies that have achieved below zero values in profit margin and ROA, have average extent of utilization of proactive non-financial measures at very low levels i.e. $1.70,2.41,1.80,1.77,1.64$, \& 1.75 in customer, operations, employee satisfaction, training \& development, community, and supplier measures respectively out of five scale points. This shows that companies which are poor in applying critical non-financial measures are inferior business performers. Pearson's correlation coefficient $r$ analysis has been done to determine the relation between business performance and non-financial measures as shown in Table 9.

\begin{tabular}{|l|c|c|c|c|}
\hline \multirow{2}{*}{\multicolumn{1}{c|}{ Performance measures }} & \multicolumn{4}{c|}{ Business performance } \\
\cline { 2 - 5 } & Profit margin & ROA & Revenue/labor & ROA/labor \\
\hline Finance & 0.20 & 0.18 & 0.30 & 0.26 \\
\hline Customer \& market & $0.68 * * *$ & $0.63 * * *$ & 0.61 & 0.45 \\
\hline Process/operation & $0.78 * * *$ & $0.69 * * *$ & 0.55 & 0.49 \\
\hline Employee satisfaction & $0.63 * * *$ & $0.58 * *$ & $0.70 *$ & 0.59 \\
\hline Training \& development & $0.67 * * *$ & $0.57 * *$ & $0.64 *$ & $0.66 *$ \\
\hline Social \& Environmental & $0.63^{* * *}$ & $0.56 * *$ & 0.67 & 0.53 \\
\hline Supplier partnership & $0.59 * * *$ & $0.65 * * *$ & 0.45 & 0.26 \\
\hline
\end{tabular}

***At significance level of $a=0.05$ and with $\rho$-value $<0.0005$;**at significance level of $a=0.05$ and with $\rho$-value $<0.005 ; *$ at significance level of $a=0.05$ and with $\rho$-value $<0.05$; and others statically not verified.

Table 9. Pearson's correlation coefficient $r$. (Researchers' computation from tables 6 \& 8)

As shown in Table 9, negligible correlations exist between business performance and financial measures and the relation also is not statistically verified. A large correlation exists between financial business performance (profit margin \& ROA) and process/operation measures. This is an indication manufacturing companies measuring their processes/operations are better performing in their finance business. Moreover the relationships between financial business performance and all non-financial measures are statistically verified. Regarding labor productivities (revenue/labor and ROA/labor), better relationships are shown with non-financial measures such as employee satisfaction and training \& development. This is because, to improve workers' productivity, companies need to motivate their employees and provide appropriate training to develop their capabilities. The above relationships between independent and dependent variables are practical and the right answers for research question \#2.

\section{Proposal of MCPM model}

This part of the paper is intended to answer research question \#3. Based on the aforementioned indications, the need assessment results and the discussion with stakeholders, the researchers proposed a MCPM model. During the time of survey and interview, the researchers realized that a considerable number of companies measure their performance with respect to customers, operations, training; but these measures are not integrated with each 
other, financial and operational measures are not aligned with the companies' strategic goals. These problems motivated the researchers to propose MCPM model which incorporates important non-financial measure. In addition, at the moment the government is insisting public companies to replace the existing finance-based traditional performance measurement and evaluation system with better and dynamic measurement systems. Therefore, it is the right time for manufacturing companies to develop reliable and sustainable MCPM model in line with the problems facing them. Managers will use the model as an important guide to develop their own specific MCPM model. Considering all these facts, the proposed MCPM model will offer a large contribution to manufacturing companies to improve their performance.

Significant features and various models are included in the proposed MCPM model. For example, it incorporates all crucial stakeholders as of Neely's (2001) Performance Prism. It starts from the vision and mission (purpose) statements and interacts with measurable performance objectives and targets similar to SMART pyramid and Kaplan and Norton Balanced Scorecard (BSC). Most of MCPM features are similar to Kaplan and Norton Balanced Scorecard. This is because of its simplicity, easy to use and it focuses on a few critical indicators not more than 25. But the limitations of BSC are mentioned by (Akkermans \& Oorschot, 2002; Flak \& Dertz, 2004; Neely, 1998), these are lack of emphasis on market, employees and suppliers not addressed, role community not determined, and contribution of other stakeholders not assessed. According to Flak and Dertz (2004), considerable organizations have modified the scorecard to make it suitable for their use, for instance, balanced IT scorecard (BITSC) and BSC of advanced information services (AISBSC).

Based on this information, some new features are included in the proposed MCPM model. In addition to four perspectives of Kaplan and Norton (1992) balanced scorecard, social and environmental, employee, market and supplier partnership perspectives are incorporated by taking into account stakeholders' feedbacks. MCPM is proposed to tackle problems that are facing companies in developing nations, especially manufacturing companies which are characterized by poor performance at the moment. The model also encourages horizontal and vertical interactions. Performance targets and objectives are usually communicated from top to bottom, but according to this model feedbacks and end results are anticipated to be communicated from bottom to top and employees at all levels are also recommended to participate during strategic plans set. These multi-directional interactions are very essential for companies which are exercising manufacturing philosophies such as TQM, concurrent engineering, BPR, benchmarking etc. which encourage teamwork and collaboration with different professionals from various divisions. 


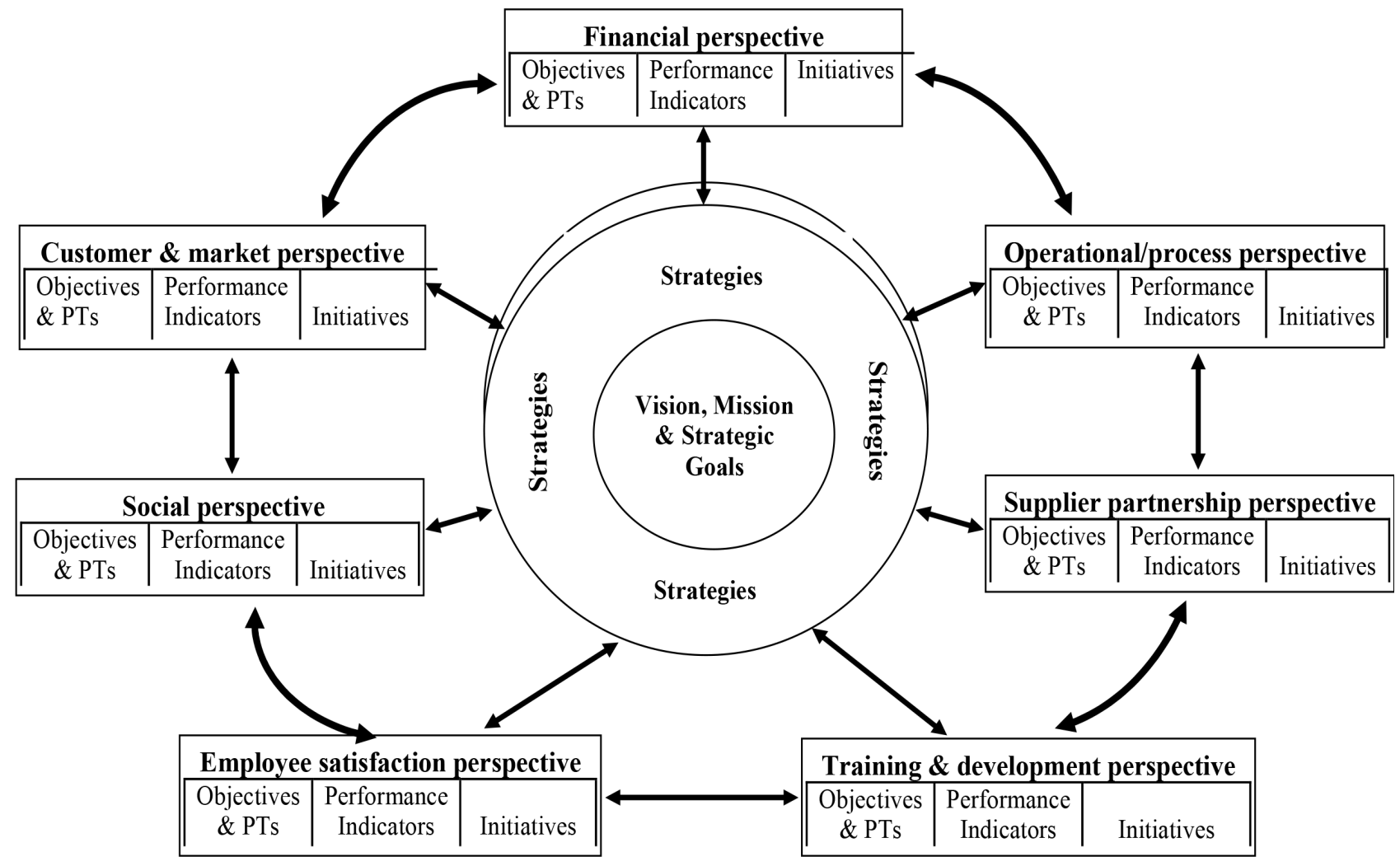

Figure 3. Proposed MCPM Model

The MCPM model has two major parts which are named "Strategy Map" and "Scorecard" which is adopted from Kaplan and Norton Balanced Scorecard. The Strategy Map is significant in order to devise cause-effect relationships between performance indicators. It has been mapped by referring standard literature sources, suggestions of respondents when researchers interviewed vital stakeholders.

The validity of the proposed causal relationship is usually verified via intensive research results with the help of PDCA (Plan-Do-Check-Act) cycle (Deming, 1986; Zhang, 2000; Morisawa \& Kurosaki, 2003). Another important part is Scorecard or Performance Measurement Sheet which consists of major measurement perspectives, performance objectives and targets, performance indicators, and initiatives. Sometimes it may incorporate baselines, weight of each target and scoring rates. The proposed performance measurement sheet consists of seven performance perspectives, twenty-one performance objectives and twenty-four performance indicators are shown in Table 10. 


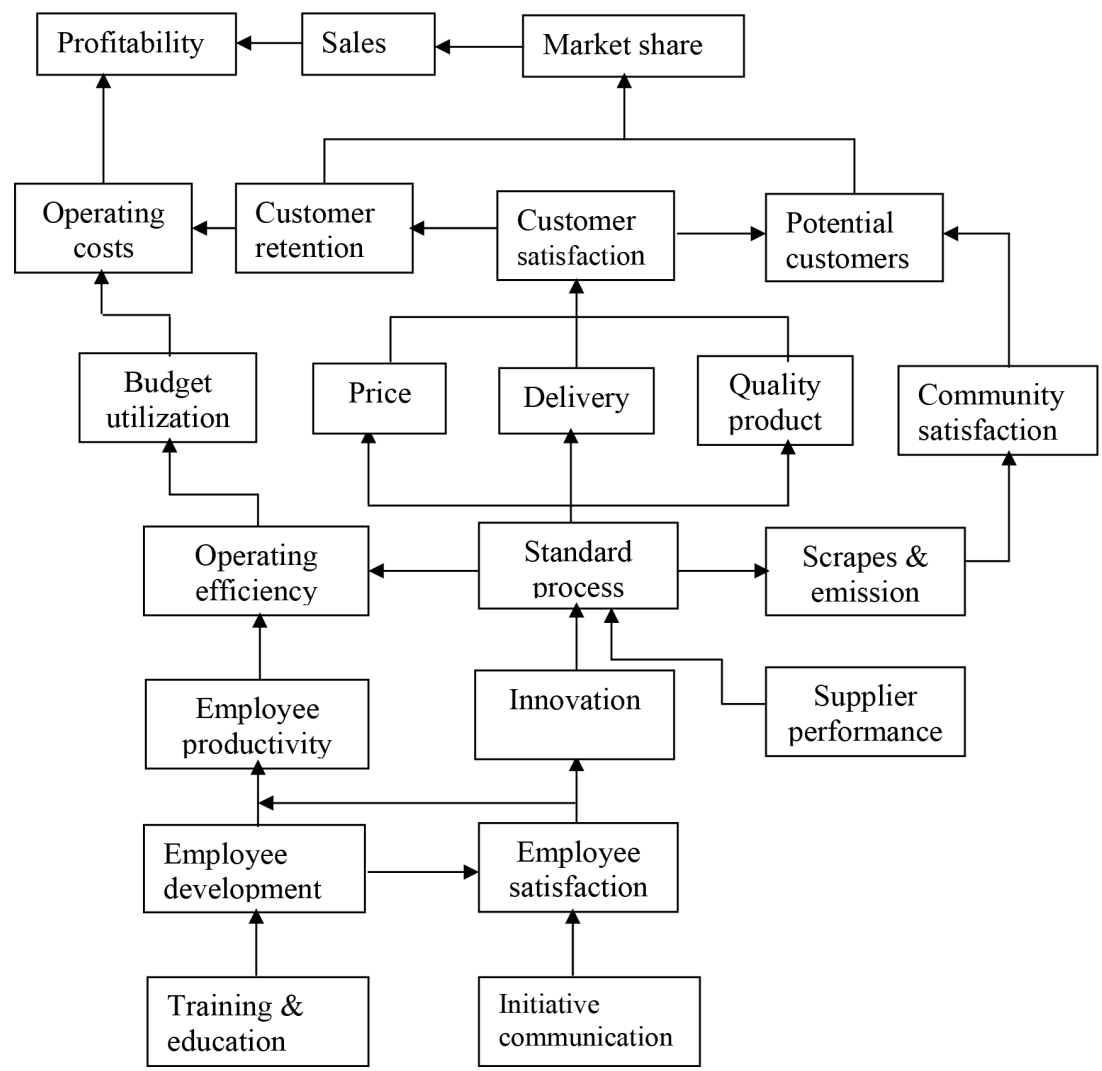

Figure 4. Strategy Map/Success Map for MCPM model development

\begin{tabular}{|c|c|c|}
\hline Performance perspectives & Performance Objectives & Performance indicators \\
\hline \multirow{3}{*}{ Finance } & \multirow{2}{*}{ Increasing profitability } & Profit margin \\
\hline & & ROA \\
\hline & Increasing revenue & Sales growth \\
\hline \multirow{4}{*}{$\begin{array}{l}\text { Customers } \\
\& \text { Market }\end{array}$} & Expansion of market share & Market share growth \\
\hline & \multirow{3}{*}{ Increasing customer satisfaction } & Satisfied customers \\
\hline & & Retained customers \\
\hline & & New customers added \\
\hline \multirow{2}{*}{ Community } & Increasing community satisfaction & Community complaints \\
\hline & Reducing pollution & Scrapes \& wastages reduced \\
\hline \multirow{4}{*}{ Operation/ Process } & Improving delivery time & Orders delivered on time \\
\hline & Enhancing product \& service quality & Failure cost (internal \& external) \\
\hline & Enhancing process efficiency & Process efficiency \\
\hline & Reducing product cycle times & Product cycle times \\
\hline \multirow{3}{*}{ Supplier } & Improving material quality & Defect rate \\
\hline & Decreasing lead time & Lead time \\
\hline & Improving raw materials costs & Raw material costs \\
\hline \multirow{3}{*}{ Employee } & Enhancing employee satisfaction & Satisfied employees \\
\hline & Reducing accidents & Accident frequency rate \\
\hline & Reduction of employee turnover & Employee turnover \\
\hline \multirow{4}{*}{ Training \& Development } & Improving employee productivity & Output/employee \\
\hline & Enhancing $R \& D$ & Innovations \\
\hline & \multirow{2}{*}{ Enhancing training \& education } & Employee skill level \\
\hline & & Qualification growth \\
\hline
\end{tabular}

Table 10. Performance Measurement Sheet 


\section{Conclusions}

Unstable and turbulent market environments are forcing manufacturing companies to improve their management styles and philosophies continuously. To attain these improvements, one of the tasks to be carried out is formulating performance measures which are able to enhance decision making for the current and future business situations. It is also revealed that traditional cost accounting measures are inadequate to provide sufficient information for predicting these future market conditions. The results discussion part of this paper has shown the business performance of most of the manufacturing companies surveyed is very low compared to international benchmarks. Moreover, the performance measurement practice of these organizations using non-financial performance measures or MCPM is low. But the extent of using financial based measures is relatively satisfactory. The correlations between important business performance and practice of non-financial measure have been shown using statistical analysis.

These findings have provided significant indications that traditional performance measures which are solely relying on financial goals and indicators fail to enhance business performance of manufacturing companies (refer Table 9).

According to the results shown in Table 9, positive relationships have been determined between financial performance and non-financial measures. Companies applying non-financial measures are achieving better business performance. Here, researchers have concluded that applying MCPM models/frameworks consisting of critical operational (non-financial) measures is the primary step for identifying problems within the companies and to take significant actions that will improve their performance in the future.

From the managerial perspective, managing labor intensive companies mean managing employees. Therefore, successes of such companies are entirely dependent on the employee's productivity and performance. The performance of such firms should be measured using leading indicators rather than lagging indicators to attain the required productivity and financial performances from their workers. This research gives an insight for those managers in two ways. Firstly, they can find empirical evidence where they are as compared to the global norms. Secondly, it will give them an idea how to improve their labor productivity and they can compete by implementing an appropriate performance measures in order to motivate and develop their workers.

As indicated in Table 9, significant positive relationships exist between employee satisfaction perspective and revenue per labor; training \& development perspective and revenue per labor; training \& development perspective and total asset per labor as compared to other perspectives. This implies companies which are measuring their performance using these two leading perspectives can achieve better labor productivity performances. Based on these facts from the research output, the proposed MCPM model is founded on these two essential 
perspectives. Strong emphasis has been provided for employee satisfaction perspective and employee training and development perspective as compared to other models devised before. This is because during the development of this model, especial features of firms have been considered i.e. they are mainly employee focused and labor intensive.

Hence, managers must be committed to devise pertinent operational strategies and measures which are aligned with vision statements and strategic goals. Existing lagging and historical performance measures should be replaced by more responsive and proactive performance in order to alleviate the challenges facing the companies in manufacturing areas. The proposed MCPM model is provided through a thorough analysis of the drawbacks and merits of numerous international models. In addition feedbacks were gathered concerning existing challenges in the manufacturing sector. Managers could use this as a basis for developing their own MCPM system.

The research is limited to manufacturing companies in a single nation. The numbers of surveyed companies are relatively small to make generalizations. Additional limitations were the subjective judgment of non-financial performance measurement practice level and biased understandings of respondents for their companies. Further research that incorporates a large number of companies from different developing nations is suggested to have a solid conclusion.

\section{References}

Abernethy, M.A., Bouwens, J., \& Van Lent, L. (2003). Determinants of Control System Design in Divisional Firms. Department of Accounting and Business Information Systems. Research Paper Series, University of Melbourne, Melbourne.

Akkermans, H., \& Oorschot, K. (2002). Developing a balanced scorecard with system dynamics. Submitted to Journal of the Operational Research Society, Netherlands.

Amaratunga, D., Baldry, D., \& Sarshar, M. (2001). Process improvement through performance measurement: the balanced scorecard methodology, work study. University of Salford, Salford, UK: MCB University Press, 50(5), 179-188.

Andersen, H.V., Lawrie, G. \& Savic, N. (2004). Effective quality management through thirdgeneration balanced, scorecard. International Journal of Productivity \& Performance Management, 53(7), 634-645. http://dx.doi.org/10.1108/17410400410561259

Artley, W. (2001). The Performance-Based Management Handbook: Establishing an Integrated Performance Measurement System. Vol. 2. University of California. 
Bamford, D., \& Chatziaslan, E. (2009). Healthcare capacity measurement. International Journal of Productivity and Performance Management, 58(8), 748-766. http://dx.doi.org/10.1108/17410400911000390

Bititci, U.S. (1994). Measuring your way to profit: a methodology leading to the development of an integrated set of performance measures. Management Decision, 32(6), 16-24. http://dx.doi.org/10.1108/00251749410065088

Bititci, U.S., Carrie, A.S., \& Mc Devitt, L. (1997). Integrated performance measurement systems: a development guide. International Journal of Operations \& Production Management, 17(5), 522-534. http://dx.doi.org/10.1108/01443579710167230

Bititci, U.S., Turner, T., \& Begemann, C. (2000). Dynamics of Performance Measurement Systems. International Journal of Operations \& Production Management, 20(6), 692-704. http://dx.doi.org/10.1108/01443570010321676

Bourne, M., Steven Melnyk, S., \& Norman Faull, N. (2007). The impact of performance measurement on performance. International Journal of Operations \& Production Management, (editorial abstract) 27(8), 779-801.

Bourne, M.C.S., Neely, A.D., Mills, J.F., \& Platts, K.W. (2003). Why Some Performance Measurement Initiatives Fail: Lessons From the Change Management Literature. International Journal of Business Performance Management, 5(2/3), 245-269. http://dx.doi.org/10.1504/IJBPM.2003.003250

Browne, J., \& Devlin, J. (1998). Performance measurement: The ENAPS Approach. University College Galway: Ireland.

Bryceson, K.P., \& Slaughter, G. (2010). Alignment of performance metrics in a multi-enterprise agribusiness: Achieving integrated autonomy? International journal of productivity and performance management, 59(4), 325-350. http://dx.doi.org/10.1108/17410401011038892

Chen, L., \& Liaw, S. (2006). Measuring performance via production management: A pattern analysis. International Journal of Productivity and Performance Management, 55(1), 79-89. http://dx.doi.org/10.1108/17410400610635516

Chen, T.Y., \& Chen, L.H. (2007). DEA performance evaluation based on BSC indicators incorporated (The case of semiconductor industry). International Journal if Productivity and Performance Management, 56(4), 335-357. http://dx.doi.org/10.1108/17410400710745333

Cheng, M.I., Dainty, A., \& Moore D. (2006). Implementing a new performance management system within a project-based organization: A case study. International Journal of Productivity and Performance Management, 56(1), 60-75. http://dx.doi.org/10.1108/17410400710717082 
Davis, S., \& Albright, T. (2004). An investigation of the effect of balanced scorecard implementation on financial performance. Management Accounting Research, 15(2), 135-153. http://dx.doi.org/10.1016/j.mar.2003.11.001

Deming, W.E. (1986). Out of the Crisis. Cambridge: Massachusetts Institute of Technology Center for Advanced Engineering Study.

Dixon, J.R., Nanni, A.J., \& Vollmann, T.E. (1990). The New Performance Challenge - Measuring Operations for World-class Competition. Dow Jones-Irwin, Homewood, IL.

Fernández-González, A.J., \& Prado Prado, J.C. (2007). Measurement and analysis of customer satisfaction: company practices in Spain and Portugal. International Journal of Productivity and Performance Management, 56(5/6), 500-517. http://dx.doi.org/10.1108/17410400710757169

Flak, L.S., \& Dertz, W. (2004). Stakeholder theory and balanced scorecard to improve is strategy development in public sector. Agder University College, Norway.

Franceschini, F., Galetto, M., \& Maisano, D. (2007). Management by Measurement: Designing Key Indicators and Performance Measurement Systems. Springer-Verlag Berlin Heidelberg.

Gilman, M., \& Metawie, M. (2005). Problems with the implementation of performance measurement systems in the public sector where performance is linked to pay: a literature review drawn from the UK. 3rd Conference on Performance Measurements and Management Control. University of Kent, Canterbury.

Gomes, C.F, Yasin, M., \& Lisboa, J. (2004). An examination of manufacturing organizations' performance evaluation: analysis, implications and a framework for future research. International Journal of Operations \& Production Management, Emerald Group Publishing Limited, 24(5), 488-513. http://dx.doi.org/10.1108/01443570410532551

Gosselin, M. (2005). An empirical study of performance measurement in manufacturing firms. International Journal of Productivity and Performance Management, 54(5/6), 419-437. http://dx.doi.org/10.1108/17410400510604566

Govindarajan, V., \& Gupta, A.K. (1985). Linking control systems to business unit strategy: impact on performance. Accounting, Organizations and Society, 10(1), 51-66. http://dx.doi.org/10.1016/0361-3682(85)90031-5

Hinton, M., \& Barnes, D. (2008). Discovering effective performance measurement for e-business. International Journal of Productivity and Performance Management, 58(4), 329-345. http://dx.doi.org/10.1108/17410400910951008 
Holloway, J. (1999). A critical research agenda for organizational performance measurement. First international critical management studies conference. Performance Management Research Unit, Manchester: Walton Hall.

Hongren, C.T., Foster, G., \& Datar, S.M. (1999). Cost Accounting: A Managerial Emphasis. Upper Saddle River, NJ: Prentice Hall.

Industrial Development Report (2004). Industrialization, Environment and the Millennium Development Goals in Sub-Saharan Africa: the new frontier in the fight against poverty. Vienna, UNIDO Publication: http://195.142.135.65/unido/documents/UNIDO_IDR2004.pdf Accessed: 22/09/2007.

Johnson, H.T., \& Kaplan, R.S. (1987). Relevance lost: The rise and fall of management accounting. Harvard Business School Press, Boston, MA.

Jyoti, Banwet, D.K., \& Deshmukh, S.G. (2008). Evaluating performance of national R\&D organizations using integrated DEA-AHP technique. International Journal of Productivity and Performance Management, 57(5), 370-388. http://dx.doi.org/10.1108/17410400810881836

Kaplan, R.S. \& Norton, D.P. (1996). Using the balanced scorecard as a strategic management system. Harvard Business Review. January-February, 75-85.

Kaplan, R.S., \& Norton, D.P. (1992). The balanced scorecard - measures that drive performance. Harvard Business Review, January-February, 71-79.

Kennerley, M., \& Neely, A. (2003). Measuring performance in a changing business environment. International Journal of Operations \& Production Management, Cranfield University, Cranfield, UK: MCB UP Limited, 23(2), 213-229. http://dx.doi.org/10.1108/01443570310458465

Kidusan, Y.W. (2004). Performance measurement practices in selected Eritrean manufacturing enterprises. Master's Thesis, Unpublished (A dissertation submitted in fulfillment of the requirements for the degree of MAGISTER COMMERCII). Bloemfontein, Republic of South Africa.

Lee, H.L., \& Amaral J. (2002). Continuous and Sustainable improvement through supply chain performance management. Stanford Global Supply Chain Management Forum Paper SGSCMF, W1, 2002.

Lockamy III, A. (1998). Quality-focused performance measurement systems: a normative model. International Journal of Operations \& Production Management, Florida Agricultural and Mechanical University, Florida, USA: MCB University Press, 18(8), 740-766. 
Lynch, R.L., \& Cross, K.F. (1991). Measure Up: Yardsticks for continuous improvement. Cambridge: Blackwell Publishers.

Mano, R.S. (2010). Marketing and performance evaluations in non-profit services: "Missed" targeting in communicating stakeholders' expectations. International Journal of Productivity and Performance Management, 59(6), 555-570. http://dx.doi.org/10.1108/17410401011063948

Medori, D., \& Steeple, D. (2000). A framework for auditing and enhancing performance measurement systems. International Journal of Operations \& Production Management, 20(5), 520-533. http://dx.doi.org/10.1108/01443570010318896

Morisawa, T., \& Kurosaki, H. (2003). Using the balanced scorecard in reforming corporate management systems. Nomura Research Institute, Ltd. NRI Papers, 71.

Neely, A. (1998). Performance Measurement: Why, What and How Economist Books, London.

Neely, A. (1999). The performance measurement revolution: why now and what next? International Journal of Operations \& Production Management, University of Cambridge, UK: MCB University Press, 19(2), 205-228.

Neely, A., \& Adams, C. (2000). Perspectives on Performance: The Performance Prism. In Bourne, M. (ed.). Handbook of Performance Measurement, London: Gee Publishing.

Neely, A., Adams, C., \& Crowe, P. (2001). The performance prism in practice. Measuring Business Excellence, 5(2), 6-12. http://dx.doi.org/10.1108/13683040110385142

Neely, A., Gregory, M., \& Platts, K. (1995). Performance measurement system design: a literature review and research agenda. International Journal of Operations \& Production Management, 15(4), 80-116. http://dx.doi.org/10.1108/01443579510083622

Neely, A., Mills, J., Platts, K., Richards, H., \& Bourne, M. (2000). Performance measurement system design: developing and testing a process-based approach. International Journal of Operations \& Production $\quad$ Management. 20(10), 1119-1145. http://dx.doi.org/10.1108/01443570010343708

Neely, A., Richards, H., Mills, J., Platts, K., \& Bourne, M. (1997). Designing performance measures: a structured approach. International Journal of Operations \& Production Management, 17(11), 1131-1152. http://dx.doi.org/10.1108/01443579710177888

Otley, D. (1999). Performance management: a framework for management control systems research. Management Accounting Research, 10(4), 363-382. 
Parida, A. (2006). Development of multi-criteria hierarchical framework for maintenance performance measurement: concepts, issues and challenges. Doctoral Thesis, Unpublished, Luleå University of Technology.

Parmenter, D. (2010). Key Performance Indicators Developing, Implementing, and Using Winning KPIs, $2^{\text {nd }}$ Ed., John Wiley \& Sons.

Radnor, Z.J., \& Barnes D. (2007). Historical analysis of performance measurement and management in operations management. International Journal of Productivity and Performance Management, 56(5/6), 284-397. http://dx.doi.org/10.1108/17410400710757105

Sahay, B.S. (2004). Multi-factor productivity measurement model for service organization. International Journal of Productivity and Performance Management, 54(1), 7-22. http://dx.doi.org/10.1108/17410400510571419

Scott, T.W., \& Tiessen, P. (1999). Performance measurement and managerial teams. Accounting, Organizations and Society, 24(3), 263-285. http://dx.doi.org/10.1016/S03613682(98)00060-9

Shahin, A., \& Mahbod, M.A. (2007). Prioritization of key performance indicators: An integration of analytical hierarchy process and goal setting. International Journal of Productivity and Performance Management, 56(3), 226-240. http://dx.doi.org/10.1108/17410400710731437

Simons, R. (2005). Levers of Organization Design: How Managers Use Accountability Systems for Greater Performance and Commitment. Boston, MA: Harvard Business School Press.

Souza, G., Carpinetti, L., Van Aken, E., \& Groesbeck, R. (2005). Conceptual design of performance measurement and management system using a structured engineering approach. International Journal of Productivity and Performance Management, 54(5/6), 385-399. http://dx.doi.org/10.1108/17410400510604548

Spitzer, D.R. (2007). Transforming Performance Measurement: Rethinking the Way We Measure and Drive Organizational Success. New York:American Management Association.

Tangen, S. (2004). Professional practice performance measurement: from philosophy to practice. International Journal of Productivity and Performance Management, The Royal Institute of Technology, Stockholm, Sweden: Emerald Group Publishing Limited, 53(8), 726-737.

Tapinos, E., Dyson, R.G., \& Meadows, M., (2005). The impact of performance measurement in strategic planning. International Journal of Productivity and Performance Management, 54(5/6), 370-384. http://dx.doi.org/10.1108/17410400510604539 
Valiris, G., \& Chytas, P. (2005). Making decisions using the balanced scorecard and the simple multi-attribute rating technique: performance measurement and metrics. University of Aegean, Chios, Greece: Emerald Group Publishing Limited, 6(3), 159-171.

White, G.P. (1996). A survey and taxonomy of strategy-related performance measures for manufacturing. International Journal of Operations \& Production Management, Southern Illinois University, Carbondale, USA: MCB University Press, 16(3), 42-61. http://dx.doi.org/10.1108/01443579610110486

Yuksel, H. (2004). An empirical evaluation of problems in performance measurement systems of big sized firms in turkey. $2^{\text {nd }}$ world conference on POM \& $15^{\text {th }}$ annual POM conference, University of Dokuz Eylul: Turkey.

Zairi, M. (1996). Effective Benchmarking - Learning from the Best. Chapman \& Hall, London.

Zhang, Z. (2000). Implementation of total quality management: An empirical study of Chinese manufacturing firms. Doctoral Thesis, University of Groningen in the Netherlands.

\section{Annex: Survey Questionnaire}

\section{General Information}

Company name Company address

Current position Highest Qualification

Work experience [year] Types of Ownership

№ of full-time employees

\section{Business performance results}

Please, fill the table below with appropriate values that have been recorded \& documented before from your company's performance evaluation reports.

\begin{tabular}{|l|l|l|l|l|}
\hline \multirow{2}{*}{ Performance Criteria } & \multicolumn{3}{c|}{ Budget Year } \\
\cline { 3 - 5 } & Year 1 & Year 2 & Year 3 & Year 4 \\
\hline Sales & & & & \\
\hline Production & & & & \\
\hline Cost of Production & & & & \\
\hline Profit before income tax & & & & \\
\hline Total Asset & & & & \\
\hline
\end{tabular}

To what extent does your company utilize performance measures that are described below during strategic performance evaluation? Please tick (X) mark on space provided in each table with a scale of five points. (Score of 5 =Very Highly, $4=$ Highly, $3=$ Moderately, $2=$ Lowly, \& $1=$ Very Lowly). 


\subsection{Financial Measures}

\begin{tabular}{|c|l|c|c|c|c|c|}
\hline \multirow{2}{*}{ S/N } & \multicolumn{1}{|c|}{ Description performance measures } & \multicolumn{3}{c|}{ Score } \\
\cline { 5 - 6 } & \multicolumn{1}{|c|}{$\mathbf{1}$} & $\mathbf{2}$ & $\mathbf{3}$ & $\mathbf{4}$ & $\mathbf{5}$ \\
\hline 1 & Total sales volume/growth & & & & & \\
\hline 2 & Operating profit & & & & \\
\hline 3 & Return on asset/capital employed & & & & & \\
\hline 4 & Return on investment & & & & \\
\hline
\end{tabular}

\subsection{Customer and Market Measures}

\begin{tabular}{|c|c|c|c|c|c|c|}
\hline \multirow{2}{*}{$\mathbf{S} / \mathbf{N}$} & \multirow{2}{*}{ Description performance measures } & \multicolumn{5}{|c|}{ Score } \\
\hline & & 1 & 2 & 3 & 4 & 5 \\
\hline 1 & Increase in market share & & & & & \\
\hline 2 & Reduction in customer complaint & & & & & \\
\hline 3 & Increase customer retention/ acquisition & & & & & \\
\hline 4 & Customer profitability & & & & & \\
\hline
\end{tabular}

\subsection{Internal Process/Operation Measures}

\begin{tabular}{|c|c|c|c|c|c|c|}
\hline \multirow{2}{*}{$\mathbf{S} / \mathbf{N}$} & \multirow{2}{*}{ Description performance measures } & \multicolumn{5}{|c|}{ Score } \\
\hline & & 1 & 2 & 3 & 4 & 5 \\
\hline 1 & Improvement in product and service quality & & & & & \\
\hline 2 & Reduction in manufacturing lead time (MLT) & & & & & \\
\hline 3 & Reduction in operating costs & & & & & \\
\hline 4 & Improvement in operating efficiency & & & & & \\
\hline 5 & Down time \& machineries availability & & & & & \\
\hline
\end{tabular}

\subsection{Employee Satisfaction Measures}

\begin{tabular}{|c|l|c|c|c|c|c|}
\hline \multirow{2}{*}{$\mathbf{S} / \mathbf{N}$} & \multicolumn{1}{|c|}{ Description performance measures } & \multicolumn{3}{c|}{ Score } \\
\cline { 5 - 6 } & & & $\mathbf{2}$ & $\mathbf{3}$ & $\mathbf{4}$ & $\mathbf{5}$ \\
\hline 1 & Employee complaint /satisfaction & & & & \\
\hline 2 & Employee retention /turnover/absenteeism & & & & \\
\hline 3 & Accidents and working environment & & & & & \\
\hline 4 & Salary, incentive and reward & & & & \\
\hline
\end{tabular}

\subsection{Training \& Development Measures}

\begin{tabular}{|c|c|c|c|c|c|c|}
\hline \multirow{2}{*}{$\mathbf{S} / \mathbf{N}$} & \multirow{2}{*}{ Description performance measures } & \multicolumn{5}{|c|}{ Score } \\
\hline & & 1 & 2 & 3 & 4 & 5 \\
\hline 1 & Training and education & & & & & \\
\hline 2 & Skill \& capacity development & & & & & \\
\hline 3 & Qualification growth & & & & & \\
\hline 4 & Innovation (new products, methods, ideas, etc) & & & & & \\
\hline
\end{tabular}




\subsection{Social and Environmental Measures}

\begin{tabular}{|c|l|l|l|l|l|l|}
\hline \multirow{2}{*}{ S/N. } & \multicolumn{1}{|c|}{ Description performance measures } & \multicolumn{5}{c|}{ Score } \\
\cline { 5 - 7 } & & $\mathbf{1}$ & $\mathbf{2}$ & $\mathbf{3}$ & $\mathbf{4}$ & $\mathbf{5}$ \\
\hline 1 & Market stabilization & & & & & \\
\hline 2 & Waste treatment \& pollution control & & & & & \\
\hline 3 & Cash outflow for social security & & & & & \\
\hline 4 & Society complaint/satisfaction & & & & & \\
\hline
\end{tabular}

\subsection{Supplier Partnership Measures}

\begin{tabular}{|c|c|c|c|c|c|c|}
\hline \multirow{2}{*}{$\mathbf{S} / \mathbf{N}$} & \multirow{2}{*}{ Description performance measures } & \multicolumn{5}{|c|}{ Score } \\
\hline & & 1 & 2 & 3 & 4 & 5 \\
\hline 1 & Materials quality & & & & & \\
\hline 2 & Delivery time & & & & & \\
\hline 3 & Materials cost & & & & & \\
\hline
\end{tabular}

\section{Need of multi-criteria performance measurement approach and pre-conditions}

For questions below, please choose and circle the number among given alternatives on the behalf your company.

- The need for your company to use a performance measurement system that integrates financial \& non-financial measures is 1) Low 2) Moderate 3) High

- Do you agree the following performance measures to be included as organization's strategic goal \& performance evaluation criteria? Please choose 'Yes' or 'No' and tick (X) mark on space provided in a table.

\begin{tabular}{|c|l|c|c|}
\hline S/N & \multicolumn{1}{|c|}{ Description } & Yes & No \\
\hline 1 & Financial perspectives & & \\
\hline 2 & Customer perspectives & & \\
\hline 3 & Internal process & & \\
\hline 4 & Employee perspectives & & \\
\hline 5 & Learning, growth \& innovation perspectives & & \\
\hline 6 & Supplier perspectives & & \\
\hline 7 & Social perspectives & & \\
\hline
\end{tabular}

- How often should the performance evaluation be reported? 1) Weekly 2) Monthly 3) Quarterly 4) Twice a Year 5) Yearly

- To what extent would the following pre-condition be fulfilled for a successful multicriteria performance measurement system implementation? And tick (X) mark on space provided in a table to indicate your choice. 


\begin{tabular}{|r|l|l|l|l|}
\hline \multicolumn{1}{|c|}{ Pre-conditions } & Fully & Moderate & Hardly/not \\
\hline 1 & Top management commitment & & & \\
\hline 2 & Every body's commitment & & & \\
\hline 3 & Working culture change & & & \\
\hline 4 & Transparency, trust, honesty \& responsibility & & & \\
\hline
\end{tabular}

Journal of Industrial Engineering and Management, 2013 (www.jiem.org)

\section{(a)}

Article's contents are provided on a Attribution-Non Commercial 3.0 Creative commons license. Readers are allowed to copy, distribute and communicate article's contents, provided the author's and Journal of Industrial Engineering and Management's names are included. It must not be used for commercial purposes. To see the complete license contents, please visit http://creativecommons.org/licenses/by-nc/3.0/. 